\title{
Development and release of new wheat and barley varieties for different zones and states
}

Arun Gupta, Vishnu Kumar, Charan Singh and Vinod Tiwari

ICAR - Indian Institute of Wheat and Barley Research, Karnal, Haryana, India

Article history: Received: 05 April 2017, Revised : 19 May 2017, Accepted: 21 June 2017

Citation: Gupta A, V Kumar, C Singh and V Tiwari. 2017. Development and release of new wheat and barley vartieties for diffrent zones and states. Journal of Wheat Research 9(1): 68-71. doi.org/10.25174/2249-4065/2017/70875

*Corresponding author: arun.gupta@icar.gov.in

@ Society for Advancement of Wheat and Barley Research

\section{Central released varieties}

During 2016-17, the Central Sub-Committee on Crops Standards, Notification and Release of Varieties for Agricultural Crops (CVRC) recommended the release of 14 wheat and barley varieties; 8 of bread wheat, 3 of durum varieties and 3 barley varieties vide notification number 2238(E) dated 29.06.16, 3540(E) dated 22.11.2016 and 1007 (E) dated 30.03.2017.

\section{Bread Wheat}

1. Raj 4238 (HW2021/RAJ3765) was developed by RARI, Durgapura for irrigated late sown conditions of Central Zone. The average grain yield is $45.5 \mathrm{q} / \mathrm{ha}$ and maximum grain yield potential is $62.8 \mathrm{q} / \mathrm{ha}$. It is good for chapatti making.

2. HS 562 (OASIS/SKAUZ//4*BCN /3/2*PASTOR) was developed by ICAR- IARI RS, Shimla for both timely sown rainfed and irrigated conditions of Northern Hills zone. Average grain yield under rainfed conditions is $36.0 \mathrm{q} / \mathrm{ha}$ and $52.7 \mathrm{q} / \mathrm{h}$ under irrigated conditions. The genotype is resistant to yellow rust.

3. PBW 660 (WG6761/WG6798) was developed by PAU, Ludhiana for rainfed, timely sown conditions of NWPZ. Average grain yield of the variety is $35.3 \mathrm{q} / \mathrm{ha}$ and it has a potential of $49.3 \mathrm{q} / \mathrm{ha}$. It is good for chapati quality.

4. HD 3171 (PBW 343/HD2879) was developed by ICARIARI, Delhi for timely sown rainfed conditions of NEPZ. It is resistant to all the three rusts i.e. yellow, brown and black rust. Its average grain yield is $28.0 \mathrm{q} / \mathrm{ha}$ and has a potential of $46.3 \mathrm{q} / \mathrm{ha}$.

5. WB2 (T.DICOCCONCI9309/AE. SQUARROSA (409)/3/MILAN/S87230//BAV92/4/2*MILAN/ S87320//BAV92) was developed by ICAR-IIWBR, Karnal for irrigated timely sown conditions of NWPZ.
Its average grain yield is $51.6 \mathrm{q} / \mathrm{ha}$ and potential is $58.9 \mathrm{q} / \mathrm{ha}$. It is a zinc-rich $(42.0 \mathrm{ppm})$ wheat variety having resistance to yellow and brown rusts.

6. HI 1605 (Pusa Ujala) (BOW/VEE/5/ND/VG9144// $\mathrm{KAL} / \mathrm{BB} / 3 / \mathrm{YACO} / 4 / \mathrm{CHIL} / 6 / \mathrm{CASKOR} / 3 / \mathrm{CROC} \_1 /$ AE.SQUARROSA(224)//OPATA/7/PASTOR/MILAN/ KAUZ/3/BAV92). The variety was developed by ICARIARI, Regional station, Indore for restricted irrigated timely sown conditions of PZ. It has resistance to brown and black rust and possesses excellent chapati making quality. Its average grain yield is $29.1 \mathrm{q} /$ ha with potential of $44.0 \mathrm{q} / \mathrm{ha}$.

7. PBW 723 (Unnat PBW343) (PBW343+Lr57/Yr40+Lr37/ Yr17) was developed by PAU, Ludhiana for irrigated timely sown conditions of NWPZ. Its average grain yield is $49.2 \mathrm{q} / \mathrm{ha}$ with a potential of $63.2 \mathrm{q} / \mathrm{h}$. It has resistance to yellow and brown rusts.

8. HPBW $01(P B W 1 Z n)$ (T. DICOCCON CI9309/ AE.SQUARROSA(409)/3/M ILAN / S 87230 // BAV92/4/2*MILAN/S87320//BAV92) was developed for irrigated timely sown conditions of NWPZ by PAU, Ludhiana. Its average grain yield is $51.7 \mathrm{q} / \mathrm{ha}$ and potential is $64.8 \mathrm{q} / \mathrm{ha}$. It is a zinc-rich wheat variety having resistance to yellow and brown rusts.

\section{Durum Wheat}

1. HD 4728 (Pusa Malwi) (ALTAR84/STINT// SILVER453/SOMAI3.1 /4/GREEN14/YAV10/AUK) was developed by IARI, New Delhi for irrigated timely sown conditions of Central Zone. Besides, good grain quality, its average grain yield is $54.2 \mathrm{q} /$ ha with yield potential of $75.1 \mathrm{q} /$ ha. 
2. MACS 3949 (STOT//ALTAR84/ALD/3/THB/ CEP7780//2*MUSK_4) was developed by ARI, Pune for irrigated timely sown conditions of Peninsular Zone. Its average grain yield is $44 \mathrm{q} / \mathrm{ha}$ and potential is $64.3 \mathrm{q} /$ ha. It has resistance to stem and leaf rusts and good pasta making quality.

3. HI 8759 (Pusa Tejas) (HI8663/HI8498) was developed by ICAR-IARI Regional Station, Indore for irrigated timely sown conditions of Central Zone. Its average grain yield is $56.9 \mathrm{q} / \mathrm{ha}$ and potential is $75.5 \mathrm{q} / \mathrm{ha}$. It is good for pasta making.

\section{Barley}

1. DWRB 123 (DWRUB54/DWR51) was developed by ICAR-IIWBR, Karnal for irrigated timely sown conditions of North Western Plains Zone. The average grain yield is $48.7 \mathrm{q} /$ ha and grain yield potential is 67.26 q/ha. DWRB123 is two-rowed malt barley and possess good malting quality characters with resistance to stripe and brown rusts.

2. RD 2849 (DWRUB52/PL705) was developed by RARI, Durgapura for irrigated timely sown conditions of North Western Plains Zone. Average grain yield of the variety is $50.9 \mathrm{q} /$ ha and it has a potential of $69.2 \mathrm{q} / \mathrm{ha}$. It is two-rowed malt barley with resistance to stripe rust.

3. RD 2794(RD2035/RD2683) was developed by RARI, Durgapura for salinity/alkalinity conditions of North Western/Eastern Plains Zones. Average grain yield under salinity conditions is $29.90 \mathrm{q} /$ ha and potential yield was recorded as $43.30 \mathrm{q} / \mathrm{ha}$. The genotype is six-row feed barley.

\section{State released varieties}

Central Sub-Committee on Crops Standards, Notification and Release of Varieties for Agricultural Crops recommended the notification of state released 15 bread wheat varieties and 1 variety each of durum wheat and barley vide notification number $112(\mathrm{E})$ dated 12.01.2016, 2238(E) dated 29.06.16, 3540(E) dated 22.11.2016 and 1007 (E) dated 30.03.2017. These varieties are:

\section{Bread Wheat}

1. PBW 658 was developed by PAU, Ludhiana. The variety is recommended for irrigated, late sown conditions in Punjab state. The variety has resistance to stripe and leaf rust and leaf blight. The average grain yield of the variety is $46.7 \mathrm{q} / \mathrm{ha}$ and its potential is $60.7 \mathrm{q} / \mathrm{ha}$.

2. MP 3382 (JW 3382)was developed by JNKVV, Jabalpur. The variety is recommended for irrigated, timely sown conditions of Madhya Pradesh state. The variety has good chapatti making quality (score:8.03/10). The average grain yield of the variety is $59.2 \mathrm{q} /$ ha and its potential is $79.4 \mathrm{q} / \mathrm{ha}$.

3. HD 3117 was developed by ICAR-IARI, New Delhi and is recommended for conservation agriculture under late sown conditions in Delhi NCR. The average grain yield of the variety is $47.9 \mathrm{q} /$ haand its potential is $50.1 \mathrm{q} /$ ha.

4. HDCSW 18 was developed by ICAR-IARI, New Delhi and it is recommended for conservation agriculture under early sown conditions of Delhi NCR. The average grain yield of the variety is $63.0 \mathrm{q} /$ ha and its potential is $73.0 \mathrm{q} / \mathrm{ha}$

5. GW 451 was developed by SDAU, Vijapur. The variety is recommended for irrigated, timely sown conditions in Gujarat state. The variety has resistance to black and brown rust. It has good grain quality. The average grain yield of the variety is $53.9 \mathrm{q} / \mathrm{ha}$ and its potential is 66.0 q/ha.

6. NIAW 1994 (Phule Samadhan) was developed by MPKV Niphad. The variety is recommended for irrigated timely sown conditions in Maharashtra, but it is suitable for both timely and late sown conditions. The average grain yield of the variety is $46.1 \mathrm{q} / \mathrm{ha}$ under timely and $44.2 \mathrm{q} / \mathrm{ha}$ under late sown conditions. Its potential is $62.0 \mathrm{q} / \mathrm{ha}$ under timely and $57.9 \mathrm{q} /$ ha under late sown conditions.

7. PBW 677 was developed by PAU, Ludhiana. The variety is recommended for irrigated, timely sown conditions in Punjab. The variety has resistance to yellow and brown rust. The average grain yield of the variety is $59.9 \mathrm{q} / \mathrm{ha}$ and its potential is $78.2 \mathrm{q} / \mathrm{ha}$.

8. PBW 725 was developed by PAU, Ludhiana. The variety is recommended for irrigated, timely sown conditions in Punjab state. The variety has high degree of resistance to yellow and brown rust. The average grain yield of the variety is $61.7 \mathrm{q} / \mathrm{ha}$ and its potential is 81.5 q/ha.

9. AKAW 4210-6 (PDKV Sardar) was developed by $\mathrm{PDKV}$, Akola. The variety is recommended for irrigated, late sown conditions in Maharashtra. It is an early maturing variety. The average grain yield of the variety is $39.2 \mathrm{q} / \mathrm{ha}$ and its potential is $62.5 \mathrm{q} / \mathrm{ha}$.

10. VL 953 was developed by ICAR-VPKAS, Almora. The variety is recommended for irrigated, timely sown conditions of Uttarakhand (Hills and Plains). The variety has resistance to yellow and brown rust. The average grain yield of the variety is $33.4 \mathrm{q} /$ ha in hills and $44.7 \mathrm{q} /$ ha in plains. 
11. UP 2784 was developed by GBPUA\&T, Pantnagar. The variety is recommended for irrigated, timely sown conditions of Uttarakhand Plains. The variety has resistance to leaf and stripe rust. The average grain yield of the variety is $44.3 \mathrm{q} / \mathrm{ha}$ and its potential is $55.2 \mathrm{q} / \mathrm{ha}$.

12. CG 1015 (Chhattisgarh Genhu-4) was developed by IGKV Regional Station, Bilaspur. The variety is recommended for irrigated, late sown conditions of Chhattisgarh. The variety has resistance to brown and black rust. The average grain yield of the variety is 36.7 $\mathrm{q} / \mathrm{ha}$ and its potential is $68.8 \mathrm{q} / \mathrm{ha}$.

13. BRW 3708 (Sabour Samridhi)was developed by BAU,Sabour. The variety is recommended for irrigated, timely sown conditions in Bihar state. The variety has resistance to leaf blight and brown rust. The average grain yield of the variety is $46.9 \mathrm{q} / \mathrm{ha}$ and its potential is $51.8 \mathrm{q} / \mathrm{ha}$.

14. BRW 934 (Sabour Shreshtha)was developed by BAU Sabour. The variety is recommended for irrigated, late sown conditions in Bihar. The variety has resistance to loose smutand brown rust. The average grain yield of the variety is $43.1 \mathrm{q} / \mathrm{ha}$ and its potential is $54.0 \mathrm{q} / \mathrm{ha}$.

15. DH 114 (Himpratham) was developed by CSK HPKVV, Palampur. The variety is recommended for higher hills in Himachal Pradesh. The variety is developed using double haploid technique.

\section{Durum Wheat}

1. MPO 1255 (MPO (JW) 1255)was developed by JNKVV- RS, Powarkheda. The variety is recommended for rainfed/restricted irrigated timely sown conditions of

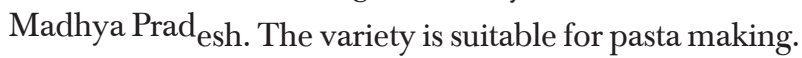
The average grain yield of the variety is $21.3 \mathrm{q} /$ ha under rainfed and $33.8 \mathrm{q} / \mathrm{ha}$ under restricted irrigation. Its potential is $34.5 \mathrm{q} / \mathrm{ha}$ and $47.3 \mathrm{q} / \mathrm{ha}$ under rainfed and restricted irrigated conditions, respectively.

\section{Barley}

1. VLB 94 was developed by ICAR-VPKAS, Almora. The variety is recommended for rainfed conditions in Uttarakhand state. The average grain yield of the variety is $18.41 \mathrm{q} / \mathrm{ha}$ and its potential is $23.08 \mathrm{q} / \mathrm{ha}$.

\section{Registration of new genetic stocks}

Thirty-six genetic stocks of wheat developed for traits like resistance to rusts, coloured grains, heat tolerance and high yellow pigment content were found suitable for registration by the Plant Germplasm Registration Committee during the year 2016-17. These genotypes were developed by IIWBR Karnal; IIWBR Regional Station Shimla; NABI Mohali; PAU Ludhiana and IARI Regional Station Indore. The details of these stocks are given in table below:

\begin{tabular}{|c|c|c|c|c|}
\hline S No & Name & $\begin{array}{l}\text { Registration } \\
\text { No. }\end{array}$ & $\begin{array}{l}\text { National } \\
\text { ID No. }\end{array}$ & Trait \\
\hline \multicolumn{5}{|c|}{ IIWBR, Karnal } \\
\hline 1 & KBRL 77-1 & INGR 15039 & IC0616061 & Resistance to Karnal bunt \\
\hline 2 & KBRL 81-1 & INGR 15043 & IC0616065 & Resistance to Karnal bunt and high 1000 grains weight \\
\hline 3 & KBRL 78-2 & INGR 15040 & IC0616062 & Resistance to Karnal bunt and high 1000 grains weight \\
\hline 4 & KBRL 83-3 & INGR 15045 & IC0616067 & Resistance to Karnal bunt and high number of tiller/m \\
\hline 5 & KBRL 79-2 & INGR 15041 & IC0616063 & Resistance to Karnal bunt and high number of tiller/m \\
\hline 6 & KBRL 82-2 & INGR 15044 & IC0616066 & Resistance to Karnal bunt and high number of grains per spike \\
\hline 7 & KBRL 80-3 & INGR 15042 & IC0616064 & Resistance to Karnal bunt and high number of grains per spike \\
\hline 8 & LBRIL102 & INGR 15060 & IC0611477 & Resistance to leaf blight \\
\hline 9 & LBRIL 189 & INGR 16013 & IC0611476 & Resistance to leaf blight \\
\hline 10 & DDW 42 & INGR 17004 & IC0621692 & High yellow pigment content \\
\hline 11 & DBW 150 & INGR 17005 & IC0621693 & Tolerant to heat stress \\
\hline \multicolumn{5}{|c|}{ IIWBR Regional Station, Shimla } \\
\hline 12 & FLW10 & INGR 17006 & IC0621833 & Carrying yellow rust resistant gene $\operatorname{Yr} 10$ in WH 542 background \\
\hline 13 & FLW 16 & INGR 17007 & IC0621834 & Yellow rust resistant gene $\operatorname{Yr} 5$ in UP 2338 background \\
\hline 14 & FLW 21 & INGR 17008 & IC0621836 & $\begin{array}{l}\text { Resistant to yellow and brown rusts due to presence of } \operatorname{Yr} 15 \text { and } \\
\text { Lr24 genes, respectively in the background of UP } 2338\end{array}$ \\
\hline 15 & FLW 22 & INGR 17009 & IC0621837 & $\begin{array}{l}\text { Resistant to brown and yellow rusts due to presence of } \operatorname{Lr} 28 \text { and } \\
\text { YrChina } 84 \text { genes, respectively in the background of WH } 542\end{array}$ \\
\hline 16 & FWW 2 & INGR 17010 & IC0621838 & Brown rust resistant genes $L r 19+\operatorname{Lr} 24$ in the background of PBW 343 \\
\hline 17 & $\begin{array}{l}\text { Local Wheat } \\
\text { Hango }\end{array}$ & INGR 17011 & IC0621839 & Susceptible to all the three rusts \\
\hline
\end{tabular}




\begin{tabular}{|c|c|c|c|c|}
\hline SNo & Name & $\begin{array}{l}\text { Registration } \\
\text { No. }\end{array}$ & $\begin{array}{l}\text { National } \\
\text { ID No. }\end{array}$ & Trait \\
\hline \multicolumn{5}{|c|}{ NABI, Mohali } \\
\hline 18 & $\begin{array}{l}\text { NABIMG-9- } \\
\text { Blue }\end{array}$ & INGR 17001 & IC0620914 & Blue coloured grains \\
\hline 19 & $\begin{array}{l}\text { NABIMG- } \\
\text { 10-Purple }\end{array}$ & INGR 17002 & IC0620915 & Purple coloured grains \\
\hline 20 & $\begin{array}{l}\text { NABIMG-11- } \\
\text { Black }\end{array}$ & INGR 17003 & IC0620916 & Black coloured grains \\
\hline \multicolumn{5}{|c|}{ PAU, Ludhiana } \\
\hline 21 & PAU 16055 & INGR 15046 & IC0616571 & $\begin{array}{l}\text { Resistance to leaf and stripe rusts and carrying } L r 57 \text { and } Y r 40 \\
\text { genes transferred from Ae. geniculata }\end{array}$ \\
\hline 22 & PAU 16062 & INGR 15051 & IC0616577 & $\begin{array}{l}\text { Resistance to leaf and stripe rusts and carrying } \operatorname{Lr} 57 \text { and } \mathrm{Yr} 40 \\
\text { genes transferred from Ae. geniculata }\end{array}$ \\
\hline 23 & PAU 16057 & INGR 15047 & IC0616573 & $\begin{array}{l}\text { Resistance to leaf and stripe rusts carrying leaf and stripe rust } \\
\text { resistance genes } L r U \text { and } Y r U \text { transferred from Ae. umbellulata } \\
\text { (accession 3732) and from Ae. peregrina (accession 3519) }\end{array}$ \\
\hline 24 & PAU 16058 & INGR 15048 & IC0616574 & $\begin{array}{l}\text { Resistance to leaf and stripe rusts carrying leaf and stripe rust } \\
\text { resistant genes transferred from Ae. peregrina (PAU accession 3519). }\end{array}$ \\
\hline 25 & PAU 16059 & INGR 15049 & IC0617118 & $\begin{array}{l}\text { Leaf and stripe rust resistance (APR) genes transferred from Wild } \\
\text { 'A' genome species T. monococcum (PAU 16059) into wheat cv. WL } \\
711 \text {. }\end{array}$ \\
\hline 26 & PAU 16060 & INGR 15050 & IC0616575 & $\begin{array}{l}\text { Resistance to leaf and stripe rusts and carrying resistance genes } \\
\text { transferred from Ae. caudata }\end{array}$ \\
\hline 27 & PBW 703 & INGR 15052 & IC0616578 & Resistance to leaf rust and stripe rusts (resistant version of PBW 343) \\
\hline
\end{tabular}

IARI Regional Station, Indore

\begin{tabular}{|c|c|c|c|c|}
\hline 28 & $\begin{array}{l}\text { HI KK1 } \\
(\mathrm{NP} 4+L r 1)\end{array}$ & INGR 16024 & IC0620368 & Carrying $L r 1$ brown rust resistant gene in NP 4 background \\
\hline 29 & $\begin{array}{l}\text { HI KK2 } \\
(\mathrm{NP} 4+L r 2 a)\end{array}$ & INGR 16025 & IC0620369 & Carrying $L r 2 a$ brown rust resistant gene in NP 4 background \\
\hline 30 & $\begin{array}{l}\text { HI KK3 } \\
(\mathrm{NP} 4+L r 2 c)\end{array}$ & INGR 16026 & IC0620370 & Carrying $L r 2 c$ brown rust resistant gene in NP 4 background \\
\hline 31 & $\begin{array}{l}\text { HI KK4 } \\
(\mathrm{NP} 4+L r 3 a)\end{array}$ & INGR 16027 & IC0620371 & Carrying $L r 3 a$ brown rust resistant gene in NP 4 background \\
\hline 32 & $\begin{array}{l}\text { HI KK5 } \\
(\mathrm{NP} 4+L r 9)\end{array}$ & INGR 16028 & IC0620372 & Carrying $\operatorname{Lr} 9$ brown rust resistant gene in NP 4 background \\
\hline 33 & $\begin{array}{l}\text { HI KK6 } \\
\text { (NP4+Lr10) }\end{array}$ & INGR 16029 & IC0620373 & Carrying $\operatorname{Lr} 10$ brown rust resistant gene in NP 4 background \\
\hline 34 & $\begin{array}{l}\text { HI KK7 } \\
(\mathrm{NP} 4+L r 75)\end{array}$ & INGR 16030 & IC0620374 & Carrying $\operatorname{Lr} 15$ brown rust resistant gene in NP 4 background \\
\hline 35 & $\begin{array}{l}\text { HI KK8 } \\
\text { (NP4+Lr77a) }\end{array}$ & INGR 16031 & IC0620375 & Carrying $L r 17 a$ brown rust resistant gene in NP 4 background \\
\hline 36 & $\begin{array}{l}\text { HI KK9 } \\
(\mathrm{NP} 4+L r 20)\end{array}$ & INGR 16032 & IC0620376 & Carrying $\operatorname{Lr} 20$ brown rust resistant gene in NP 4 background \\
\hline
\end{tabular}

